\title{
AKT1 Gene Mutation
}

National Cancer Institute

\section{Source}

National Cancer Institute. AKT1 Gene Mutation. NCI Thesaurus. Code C98304.

A change in the nucleotide sequence of the AKT1 gene. 